\title{
Toward a new conceptualization of citizenship in Turkey
}

\author{
Şerif Esendemir \\ Department of Sociology. Faculty of Arts and Sciences, Yildiz Technical University, İstanbul, Turkey. \\ Received 9 September, 2014; Accepted 24 August, 2015
}

\begin{abstract}
The traditional form of citizenship has always been determined by the nation-state throughout the world. However, recently the development of new rights, international migration, and globalization affects the practice of citizenship. As a result, many scholars started to either redefine or develop alternative concepts of citizenship. In this context, Turkey is not an exception to the rule in its reconceptualization of the notion of citizenship. In particular, the concept of "Citizen of Turkey" used by the president-elect Erdogan brought to the forefront a critical debate on the definition of citizenship as a "new Turkey" is being founded. The aim of this article is to create an analytical framework to parse out the debates on this hot topic. In turn, this will enrich the legislative discussions to be able to draft a more inclusive and new civilian Turkish Constitution. As a methodological approach in this article, two parameters of change of the classical understanding of citizenship are employed to develop new conceptions of citizenship in Turkey in relation to the European Union (EU). The former parameter of change in the traditional form of citizenship is seen through the development of rights, whereas the latter one is found in the process of membership to the nation-state. Both of these concepts are rooted in the democratic demands of social differences. Therefore, this work examines why the nation-state is not able to accommodate all new demands of its citizens having different backgrounds with its traditional form of citizenship.
\end{abstract}

Key words: Citizenship, citizen of Turkey, status, human rights, constitution, belonging and nation-state.

\section{INTRODUCTION}

Recently, the traditional form of Turkish citizenship has been questioned by scholars owing to international migration and globalization in addition to internal democratic demands of different segments of society. The tolerance of welcoming multiple citizenships is a result of this new trend (Kadirbeyoglu, 2009). In other words, the classical understanding of citizenship, with its status, membership, and the notion of belonging is being actively debated. The development of three sets of rights by Marshall (1965) and the questioning of the nation-state within the globalization process, as the provider of membership and citizenship by Bloemrad, Corteweg, and Yurdagul (2008) set the groundwork for this hot debate. Therefore, "proliferated rights," including cultural rights (Turner, 1994), identity rights (Isin and Wood, 1999), and human rights (Soysal, 1994) are the extension of Marhall's rights perspective. However,

E-mail: serif@yildiz.edu.tr

Authors agree that this article remain permanently open access under the terms of the Creative Commons Attribution License 4.0 International License 
multicultural citizenship (Kymlicka, 1995), radical-democratic citizenship (Mouffe, 2013), global citizenship (Falk, 1993), ecological citizenship (van Steenbergen, 1994), neorepublican citizenship (van Gunsteren, 1994), and constitutional/European citizenship (Habermas, 1993) are new concepts suggested for discussing the classical meaning of citizenship in terms of nation-state membership.

The classical understanding of Turkish citizenship is equally questioned due to its strong ethno-secular borders. Since Turkish nationalism shows features of both the German and French models, the question of how to be a real Turkish citizens through jus sanguines (right of blood) or Turkification became critical if one takes the argumentation of Brubaker (1992) into account. According to Brubaker (1992), descent is a major base of political identification, including citizenship, in the German model. Therefore, it is difficult for an individual from other descents to become a German. This model is completely the opposite of the French model in which an individual can more easily obtain the rights of citizenship through Frencification. However, the concept of "Citizen of Turkey" used by president-elect Erdogan during his Balcony Speech in 2014 addressed a completely new way of acquiring citizenship rights. In this article, the main focus of the discussion will be on theoretical background of this groundbreaking understanding of citizenship in Turkey.

The methodology of the work is based on a short literature review of debates on rethinking citizenship to lay down the groundwork for new discussions during the "Democratic Opening" process for developing a new constitution. Therefore, the scope of the study is limited to the critical review of debates on the constitution of citizenship revolving around old questions and new searches. In this context, one of the major questions of the study is whether or not societal peace is achievable by developing an updated concept of citizenship for negotiating drafts of a new constitution.

\section{Features of classical understanding of Turkish Citizenship}

The classical form of Turkish citizenship is based on the strong state tradition having ethno-secular borders. For example, even the Tanzimat Edict (The Reform Edict in 1839) regulated the relationship between the sultan (the head of state) and his reaya (subjects) on the basis of the classical understanding of citizenship with an imperial emphasis (Lewis, 1965). Then citizens were associated to a new Turkish nation-state membership after the sultanate system was completely replaced by the republican state in 1923.

Citizenship education is a good example of how the Turkish-state-centered approach to understand statecentered Turkish citizenship and its transformation with the process of discussing the membership of EU. Until Turkey's application to become an EU member, citizenship education aimed at creating self-sacrificing, patriotic, and duty-laden citizens. However, after Turkey's official candidacy to the EU in 1999. Turkish citizenship education involved references to universal conceptions of citizenship (Cayir and Gurkaynak, 2007). One of the tenets of $X X^{\text {th }}$ Century nationalism was the creation of a homogenous citizenship in each nation-state. However, faced with growing social pluralism and the global rise of democracy, the nationalist project of citizenship has proven to be unsustainable (Koker, 2010).

In a nutshell, the demands of different elements of society brought to the surface discussions on the process of "denationalizing" the concept of citizenship in Turkey. Consequently, many reforms were undertaken after Turkey's official candidacy the EU. Turkish state started to welcome the presence of multicultural identities and their social rights (Kadıoğlu, 2007; Yalcin-Hekman, 2011). As a result of this changing political landscape, new concepts are emerging in the debate of "What is a citizen?" in Turkey. Further, citizen activism is developing and anticipating a reply from the Turkish state.

\section{Two parameters of change in classical Turkish citizenship}

Erdogan's vision of a "citizenship" in Turkey can be best understood through the lens of what is a citizen in Europe. Accordingly, the European idea of citizenship is based on a new conception of citizenship. This ideal seeks to break the bond between a national territory and a particular social class or privileged status group. One can define Europe with nomos (law, status) and topos (territory, geography) to understand what the concept of Europe represents. Likewise, Erdogan views the concept of citizens of Turkey having territorial presence or association (topos) and legal belonging (nomos).

Although the transnational character of the EU shows an obvious extension of European citizenship in terms of geography, some thinkers oppose this idea. For example, Aron (1994) mentions that like the United States of America (USA) a possible "United States of Europe" will not be able to make citizenship multinational. In his view, the reason is that the nature of citizenship was not altered with the foundation of the USA and the adaptation of a new constitution. Thus, the rights of the citizens were simply transferred from one authority to another.

However, Turkey has a lot to learn from the experience of the U.S. and the EU to make its citizenship multicultural and inclusive through a new civilian constitution. Since citizenship has always been defined with a particular ethnic-state membership, the whole idea behind the newly coined phrase "Citizen of Turkey" is to go beyond the definition of a citizenship with ethno-secular borders. Erdogan tried to go beyond 
this limitation by using residency as the base which holds a legal status.

Nevertheless, Delanty (1997) and Faulks (2000) criticize European citizenship because European citizenship is still limited to citizens of its member states. Therefore, it is not inclusive enough to incorporate Gastarbeiter (Guest Workers), immigrants, and uprooted people such as the Turkish diaspora in Gemany. Therefore, although the concept of "Citizen of Turkey" seems to only refer to the geography of Turkey, it opens a way to welcome the individuals from other nations preferring to live and invest in Turkey. In fact, with developments of economy and social rights Turkey has become a "welfare zone" for citizens from all around the world.

One can argue that the EU is one of the well-known examples of transnational organizations today. Although the EU appears hesitant to take on a leadership role in defining global issues, its formidable organizational and institutional capacity makes a difference in the daily lives of many. Especially with the rise of serious global problems the need for transnational organizations has become more evident. It seems that the EU has a potential to play an important role in activating transnational principles to solve these problems. So, the EU might become a legitimate power block if these principles were to be enacted by a European citizenship with a universal responsibility.

The extension of the territorial aspect of European citizenship can be seen in two ways. First, international economic activities among the EU's member states played a strong role in undermining their national territorial focuses. In Turkey's case, through its candidacy to the EU, it has worked towards creating a common ground for the extension of European ideals in Turkey, which is further bolstered by the international economy and its interdependence.

Secondly, there is an obvious tendency toward nomos in Europe because the concept of European citizenship gives a privileged status to its citizens because of the rule of law in the Union. For instance, the European Court of Human Rights (ECHR) with a common constitution is illustrative of how this system functions. The work done by ECHR in the area of human rights shows a proliferation of rights as well as their extension beyond any community in the global era. That is to say, since all citizens have the same rights and duties guaranteed by the constitution, there is not the hegemony of a particular class or community over the others. Thus, no social status group has an opportunity to dominate the others.

\section{Transformation of classical understanding of Turkish Citizenship}

It was not the first time Erdogan tried to open a new way to debate traditional Turkish citizenship. For example, he even mentioned the concept of "Citizenship of Turkey" as a supra-identity during his Semdinli Speech in 2005. Although, Turkey's traditional concept of citizenship is founded on ethno-secular groups, citizenship has taken on a much broader - umbrella like role today. In fact, his new understanding is groundbreaking, especially given the view point of Turkey's militaristic elite in defining a "so-called citizen" according to ethno-secular groups.

Reiterating the point above, change is happening in how Turks view citizenship. But the most important question is whether or not these dramatic changes are profoundly affecting the traditional form of Turkish citizenship. One can answer this question as follows:

First, the constitutional right to speak and broadcast in one's mother-tongue, other than Turkish has contributed to the rate of increased representation of different ethnicoriented elements of Turkish society in the public space by the means of education. Thus, passive citizenship was replaced by an active one.

Second, there are further improvements in human rights category in Turkey. As a result, the traditional form of Turkish citizenship moves slightly closer to a new definition of the constitutional/European citizenship, where human rights are a fundamental part of citizenship.

Finally, the right of religious groups to own property, even minority religious groups, is reflective of the democratic reform process in Turkey. This reform should be contrasted with the previous practice under the Single Party Period (1923-1950) where such property was heavily taxed. For this reason, the concept of citizenship has begun to almost attain its real meaning in Turkey. The extent of the traditional form of Turkish citizenship expanded a little further with economic participation of religious affiliated elements of society. Consequently, citizenship became more active due to the inclusion of different societal and religious groups as well as offering more opportunities in the public space.

\section{Conclusion}

The realization of TV broadcasting in different languages and the application of the Democratic Opening Process with the initiative of the Justice and Development Party (AK Parti) accelerated the progress of change in classical Turkish citizenship with its topographic and status aspects. Such a groundbreaking development stemmed from the push of globalization and rise of demand for democratic rights. In other words, the state realized how it is difficult to accommodate societal differences with a traditional form of citizenship, as it is exclusionary. Therefore, an updated inclusive model of citizenship became a necessity to embrace all segments of society. That is what we call the extension in individual status in terms of rights in addition to a radical change in the national/local perspective of the state toward a more 
comprehensive universal/global one.

The bottom line is that not only citizenship has started to include differences under the same social status with the process of Turkey's candidacy for EU membership, but it also began to go beyond its classical national territorial boundaries with the rise of internationalism/ universalism and the civilization perspective. If this process is going to continue in both of these directions, new conceptional visions of citizenship can be imagined. The use of "Citizens of Turkey" encouraged academicians and politicians to bring their suggestions to the table during the debates on the drafting of a new constitution. Without a doubt, a new constitution represents a big chance for Turkey to have an inclusive model citizenship regardless of nationality, religion, race, and gender of an individual with the guarantee of universal human rights, duties, and the rule of law.

\section{Conflict of Interests}

The author has not declared any conflict of interests.

\section{ACKNOWLEDGEMENTS}

The author declared that this study was conducted at the Yildiz Technical University, Istanbul, Turkey. First of all, the author owes a great thanks to his colleagues from the Department of Sociology for their heartening efforts in its international publication. A great thanks also to his wife Neriman Esendemir, for her moral support. Finally, his deep thanks go to Nathania Ustun for proofreading and making sure it had to be submitted on time.

\section{REFERENCES}

Aron R (1974). Is Multinational Citizenship Possible? Soc. Res. 41(4):638-656.

Bloemrad I, Corteweg A, Yurdagul G (2008). Citizenship and Immigration: Multiculturalism, Assimilation, and Challenges to the Nation-State. Ann. Rev. Sociol. 34:153-79

Brubaker R (1992). Citizenship and Nationhood in France and Germany. Cambridge, MA: Harvard University Press.

Cayir K, Gurkaynak I (2007). The State of Citizenship Education in Turkey: Past and Present. J. Soc. Sci. Educ. 6 (2):50-58.

Delanty G (1997). Models of Citizenship: Defining European Identity and Citizenship. Citizenship Stud. 1(3):285-303.

Falk R (1993). The Making of Global Citizenship. In Global Visions: Beyond the New World Order. J. Brecher, J. B. Childs, J. Cutler (eds.). Boston: South End Press. pp.39-50.
Faulks K (2000). Citizenship. London and New York: Routledge.

Habermas J (1993). Struggles for Recognition in Constitutional States. Euro. J. Philo. 1(2):128-155.

Isin E, Wood PK (1999). Citizenship \& Identity. London: Sage.

Kadioglu A (2007). Denationalization of Citizenship? The Turkish Experience1. Citizenship Stud. 11(3):283-299.

Kadirbeyoglu Z (2009). Changing Conception of Citizenship in Turkey. In Citizenship Policies in the New Europe. R. Bauböck, B. Perchining (eds.). Amsterdam: Amsterdam University Press pp.419-438.

Koker L (2010). A Key to the "Democratic Opening": Rethinking Citizenship, Ethnicity and Turkish Nation-State. Insight Turkey. 12(2):49-69.

Kymlicka W (1995). Multicultural Citizenship: A Liberal Theory of Minority Rights. New York: Oxford University Press.

Lewis B (1965). The Emergence of Modern Turkey. London: Oxford University Press.

Marshall TH (1965). Class, Citizenship, and Social Development. New York: Anchor Books.

Mouffe C (2013). Democratic Citizenship and the Political Community. In Chantal Mouffe: Hegemony, Radical Democracy, and the Political. J. Martin (ed.). New York: Routledge pp.103-114.

Soysal YN (1994). Limits of Citizenship: Migrants and Postnational Membership in Europe. Chicago: The University of Chicago Press.

Turner BS (1994). Postmodern Culture/Modern Citizens. In The Condition of Citizenship. B. van Steenbergen (ed.). London: Sage. pp.153-168.

Van Gunsteren H (1994). Four Conceptions of Citizenship. In: The Condition of Citizenship. B. van Steenbergen (ed.). London, Thousand Oaks and New Delhi: Sage Publications. pp.36-48.

Van Steenbergen B (1994). Towards a Global Ecological Citizen. In The Condition of Citizenship. B. van Steenbergen (ed.). London: Thousand Oaks and New Delhi: Sage Publications. pp.141-152.

Yalçın-Heckmann L (2011). Introduction: Claiming Social Citizenship. Citizenship Studies. 15 (3-4):433-439. 